\title{
The Savings Motives: With Special Reference to Households in Kalutara District, Sri Lanka
}

\author{
P J Kumarasinghe", S C Munasinghe \\ Senior Lecturer, Department Of Business Economics, Faculty Of Management Studies And Commerce, \\ University Of Sri Jayewardenepura \\ *Corresponding author's email: Pivithuru [AT] Sjp.Ac.Lk
}

\begin{abstract}
The Main Purpose Of This Paper Is To Examine The Most Significant Savings Motive Among Households In Kalutara District. Data Was Collected Through Questionnaires By Using Hundred Respondents. The Factor Analysis Is Explored To Examine, What Is The Most Significant Savings Motive Among Pre-Determined Savings Motives Of Bequest, Precautionary And Life Cycle. It Has Been Identified The Most Significant Savings Motive Of Households In Kalutara District Is The Precautionary Savings Motive
\end{abstract}

Keywords---- Savings Behavior, Savings Motives, Factor Analysis

\section{INTRODUCTION}

The Household Savings Is The Portion Of Disposal Income Which Does Not Spent On Consumption But Accumulated Or Invested In Different Sources (Beta.Tutor2u.Net, 2015). The Decision Of Money Is Saving Is An Indicator To The Economic Performance Of A Country. Actually Savings Are Bad For Economic Growth In Short Term, Which It Reduces Economic Activities. But In Long Term Perspective It Has Favorably Effect To The Economy, Which Generates The Pool Of Money To Lending And Reduce The Real Interest Rate. So It Creates A Healthy Economy While Go For Sustaining Economy.

As For, Characteristics Of People Are Differed From One Another And They Take Decisions Rationally For Their Current And Future Betterment. Those Different Characteristics Lead People To Take Decisions Differently. People Save Money According To Different Reasons Under Diverse Savings Motives.

John Maynard Keynes Is A Person Who Has Discussed The Comprehensive List Of The Savings Motives Which Lead To Change The Role Of The Psychology Of Saving. He Described Eight Main Factors Of A Subjective Character, Which Lead Individuals To Refrain From Spending Out Of Their Incomes (Horioka And Watanabe, 1997).

The Research Problem This Study Is Why Do People Save Money In A Broader Sense And It Is Expected To Provide The Answers For What Is The Most Significant Savings Motive To Stimulate People, For Savings As The Research Question

The Main Objective Of This Research Is To Identify The Most Significant Savings Motive Which Stimulates The Savings Of Household In Kalutara District. And The Sub Objective Is To Analyze The Association Between Demographical And Socio Economic Characteristics Of Respondents With Their Motives For Saving

The Organization Of This Paper Is As Follows; Section 2 Theoretical And Empirical Review Of Saving Motives, In Section 3 Conceptual Framework And Methodology, In Section 4 Data Presentation, In Section 5 Is A Brief Discussion Of The Findings And Finally Section 6 Is The Recommendations

\section{THEORETICAL AND EMPIRICAL REVIEW}

The Purpose Of Studying The Theoretical And Empirical Research Is To Prove The Content Validity Of This Study. The Reviews Are Organized In Chronological Order.

Xiao And Noring (1994); Was Examined The Perceived Saving Motives And Hierarchical Financial Needs In United State And Has Found That Low Income Households Were More Likely To Report Saving For Daily Expenses, Middle Income Households More Likely To Report Saving For Emergency And High Income Households More Likely To Report Saving For Purchase, Retirement, Children, And Growth; After Analyzing Three Income Levels Of The Households.

Horioka And Watanabe (1997) Have Found Out That Net Saving For The Retirement And Precautionary Motives, Both Of Which Are Consistent With The Life-Cycle Model And They Are Of Dominant Importance To Examine The Contribution Of Net Saving For Each Of Twelve Motives To Overall Household Saving In Japan 
Fifteen Salient Saving Goals Were Identified By Canova, Rattazzi And Webley (2005) Stated That The Top Of The Hierarchy Are Abstract Goals Such As Self-Esteem And Self-Gratification And Bottom Parts Are Concrete Goals Such As Purchase, Holidays And Money Availability

Fisher And Montalto (2010) Figured Out That The Emergency And Retirement Saving Motives Were The Saving Motives That Significantly Increase The Likelihood Of Saving Regularly.

Yao Et Al. (2011) Compared Saving Motives Between Chinese And American Urban Households. The Results Were Indicated That Chinese Households Were More Likely To Save Money On Precautionary And Education Saving Motives Than American Households And The Chinese Households With Lower Incomes Were More Likely To Save On Retirement Saving Motive.

Hierarchical Structure Of Saving Goals Among U.S. Households Has Been Studied By Lee (2012) And Figure Out The Retirement/Security Goal Was The Most Salient Goal In Both Frequency And Percent Saved, Followed By The Emergency/Saving Goal, While The Love/Family And The Esteem/Luxury Goals Were Less Common, And Likely To Be Secondary Choices.

Birkeland (2013) Has Studied About The Saving Motives Of Dutch Households And Revealed That The Precautionary Saving Motive To Be The Most Important Saving Motive For Individuals And The Bequest Motive, The Calculation Motive And The Enterprise Motives Are Saving Motives That Are Less Important For Individuals In The Netherlands. The Study Conducted By Yao And Xiao (2014) Revealed That Emergency, Children's Education, And Retirement Were The Three Most Commonly Reported Saving Motives.

Le Blanc Et Al., (2015) Explored The Role Of Household Saving Behavior Of Individual Motives For Savings In Fifteen Euro Area Countries. They Have Figured Out That The Most Commonly Reported Saving Motives Are The Precautionary Saving And Old-Age Provision Motives, Among All Countries

The Analysis Of The Motives For Savings And The Attitudes Of Young Georgians Towards Saving Was Studied By Chudzian, Anioła-Mikołajczak And Pataraia, (2015) And Found Out The Most Often Chosen Saving Motives Were Reasons Related To Daily Functioning, Making Reserves For Everyday Needs, Purchase Of Durable Needs Or Regulating Fees.

\section{METHODOLOGY}

The Target Population Of The Study Is The Whole Population Who Are Above 18 Years Old In The District And It Was Approximately 85535 People. The Sample Size Was Restricted To Hundred (100) And The Sample Was Selected Under The Convenience Sampling Techniques. The Age Criterion Is Applied Because, As Above 18 Years Of Age Can Save In Their Own Saving Accounts In A Bank.

The Respondents Were Selected By Covering All Fourteen (14) Divisional Secretarial Divisions In Kalutara District: Panadura, Beruwala, Kalutara, Horana, Bandaragama, Mathugama, Bulathsinhala, Dodangoda, Walallawita, Ingiriya, Millaniya, Palindanuwara, Agalawatta And Madurawala. Questionnaires Were Distributed Among 10 Households Which Are Above 18 Years Old, In Each Divisional Secretarial Division. 


\section{The Conceptual Framework}

Figure1: Conceptual Framework

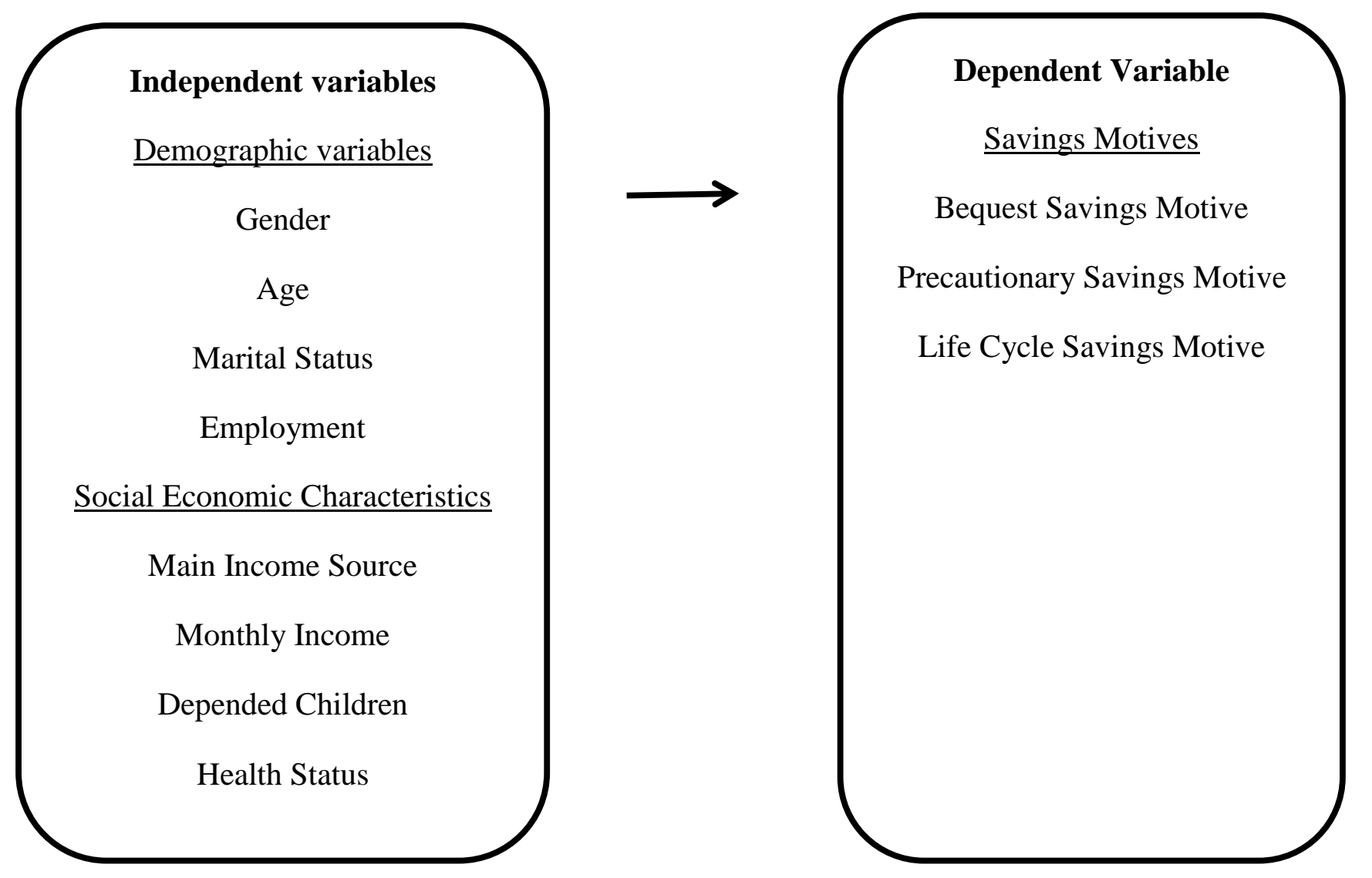

\section{Dependent Variables}

The Dependent Variables Of This Study Are Savings Motives. In The Survey Questionnaire, The Respondents Were Asked To Select The Most Significant Savings Motive Among The Given Savings Motives. The Predetermined Savings Motives Were Precautionary Savings Motive, Bequest Savings Motive And Lifecycle Savings Motive.

Independent Variables

Eight Variables Are Selected As The Independent Variables After The Referring The Empirical Reviews [Yao And Xiao (2014)]. Eight Independent Variables Were Divided In To Two Categories Demographic Variables And Socio Economic Variables.

The Study Inspects Age, Gender, Marital Status And Employment As The Demographic Variables.

The Classification Of The Socio Economic Variables Is Monthly Income, Main Income Source, Health Situation And Whether Family Includes Dependent Children Or Not

\section{The Data Collection Method}

The Research Was Conducted In The Form Of A Survey In Order To Acquire Primary Data. Respondents Were Instructed To Complete The Questionnaire As Intention To Identify Saving Purposes. Respondents Were Asked To Report Their Most Important Reasons For Saving Among Selected Savings Motives Named As Precautionary Savings Motive, Bequest Savings Motive And Lifecycle Savings Motive.

Hypothesis Of This Study For The Sub-Objective

$\mathrm{H}_{1}$ : There Is An Association Between The Demographic Variables And Bequest Savings Motive

$\mathrm{H}_{1}$ : There Is An Association Between The Socio Economic Variables And Bequest Savings Motive

$\mathrm{H}_{1}$ : There Is An Association Between The Demographic Variables And Precautionary Savings Motive

$\mathrm{H}_{1}$ : There Is An Association Between The Socio Economic Variables And Precautionary Savings Motive

$\mathrm{H}_{1}$ : There Is An Association Between The Demographic Variables And Life Cycle Savings Motive

$\mathrm{H}_{1}$ : There Is An Association Between The Socio Economic Variables And Life Cycle Savings Motive 


\section{Data Analysis Methods}

Statistical Package For The Social Sciences Was Analyzed The Gathered Data. The Factor Analysis Was Explored To Examine The Most Significant Savings Motive Among Pre-Determined Savings Motive Of Precautionary Savings Motive, Bequest Savings Motive And Lifecycle Savings Motive [Mastrogiacomo And Alessie (2011)

The Association Between The Demographic And Socio Economic Variables Such As Gender, Age, Marital Status, Employment, Main Income Source, Monthly Income, Depended Children, Health Status [Cho(2009)] And The Savings Motives Is Determined Through The Chi-Square [ Xiao And Noring (1994), Yao And Xiao (2014), Fisher And Montalto (2010)] .

\section{The Pilot Survey}

A Pilot Survey Was Conducted To Test The Reliability Of The Questionnaire By Using 12 Households In Mathugama And Dodangoda Divisional Secretarial During $5^{\text {th }}$ Of October To $11^{\text {th }}$ Of October In 2015

Table 1: Reliability Statistics Table

\section{Reliability Statistics}

\begin{tabular}{|l|l|l|}
\hline & & \\
Cronbach's Alpha & $\begin{array}{l}\text { Cronbach's Alpha Based On Standardized } \\
\text { Items }\end{array}$ & N Of Items \\
\hline .857 & .842 & 25 \\
\hline
\end{tabular}

Sources: Survey Data 2016

According To The Spss Software Cronbach's Alpha Level Of Questionnaire Of This Study Is 0.857. It Is Indicates That Higher Reliability Among The Questions In The Questionnaire And It Is Confirmed That Questionnaire Can Continue For Final Data Collection.

\section{DATA PRESENTATION AND ANALYSIS}

Main Objective: The Main Purpose Of This Study Is To Identify The Most Significant Savings Motive Among Households In Kalutara District. It Is Determined By The Factor Analysis Through Spss Software

The Component Matrix Illustrated The Factor Loadings For Each Variable. It Is Indicated 0.438 Values For Bequest Savings Motive, 0.892 Values For Precautionary Savings Motive And .0841 Values For Lifecycle Savings Motive. It Is Selected The Strongest Variable As The Most Significant Savings Motive.

Table 2: Component Matix

Component Matrix ${ }^{\mathrm{a}}$

\begin{tabular}{|c|c|c|}
\hline & \multicolumn{2}{|l|}{ Component } \\
\hline & 1 & \\
\hline Bequest & & .438 \\
\hline Precautionary & & 892 \\
\hline L_C & & 841 \\
\hline
\end{tabular}

Extraction Method: Principal Component Analysis.

A. 1 Components Extracted.

Sources: Survey Data 2016 
The Below Table Illustrate The Summary Of Association Each Variable To Each Savings Motive.

Table3: Summary Of Association Between Variables And Savings Motives

\begin{tabular}{|c|c|c|c|c|}
\hline & Variable & Savings Motive & Reject $H O$ & $\begin{array}{l}\text { Do Not Reject } \\
\text { HO }\end{array}$ \\
\hline \multirow{12}{*}{$\begin{array}{c}\text { Demographic } \\
\text { Variables }\end{array}$} & \multirow[t]{3}{*}{ Gender } & Bequest & $\checkmark$ & \\
\hline & & Precautionary & & $\checkmark$ \\
\hline & & Life Cycle & & $\checkmark$ \\
\hline & \multirow[t]{3}{*}{ Marital Status } & Bequest & & $\checkmark$ \\
\hline & & Precautionary & & $\checkmark$ \\
\hline & & Life Cycle & $\checkmark$ & \\
\hline & \multirow[t]{3}{*}{ Age } & Bequest & & $\checkmark$ \\
\hline & & Precautionary & & $\checkmark$ \\
\hline & & Life Cycle & & $\checkmark$ \\
\hline & \multirow[t]{3}{*}{ Employment } & Bequest & & $\checkmark$ \\
\hline & & Precautionary & & $\checkmark$ \\
\hline & & Life Cycle & $\checkmark$ & \\
\hline \multirow{12}{*}{$\begin{array}{c}\text { Socio- } \\
\text { Economic } \\
\text { Variables }\end{array}$} & \multirow[t]{3}{*}{$\begin{array}{l}\text { Monthly } \\
\text { Income }\end{array}$} & Bequest & & $\checkmark$ \\
\hline & & Precautionary & & $\checkmark$ \\
\hline & & Life Cycle & & $\checkmark$ \\
\hline & \multirow{3}{*}{$\begin{array}{l}\text { Main Income } \\
\text { Source }\end{array}$} & Bequest & & $\checkmark$ \\
\hline & & Precautionary & & $\checkmark$ \\
\hline & & Life Cycle & $\checkmark$ & \\
\hline & \multirow{3}{*}{$\begin{array}{l}\text { Dependent } \\
\text { Children }\end{array}$} & Bequest & $\checkmark$ & \\
\hline & & Precautionary & & $\checkmark$ \\
\hline & & Life Cycle & & $\checkmark$ \\
\hline & \multirow{3}{*}{$\begin{array}{l}\text { Health } \\
\text { Status }\end{array}$} & Bequest & & $\checkmark$ \\
\hline & & Precautionary & & $\checkmark$ \\
\hline & & Life Cycle & & $\checkmark$ \\
\hline
\end{tabular}

Sources: Survey Data 2016

\section{DISCUSSION AND CONCLUSION}

The Main Purpose Of This Study Is To Identify The Most Significant Savings Motive. The Respondents Were Asked To Report Their Most Important Reason For Saving Among Selected Savings Motives; Precautionary Savings Motive, Bequest Savings Motive And Lifecycle Savings Motive. After Analyzing The Records Of The Respondents Through Factor Analysis, It Is Identified The Most Significant Savings Motive Of Households In Kalutara District Is The Precautionary Savings Motive. The Analysis Reveals That The Second Important Savings Motive Is The Lifecycle Savings Motive And Least Importance Is Given To The Bequest Savings Motive.

Precautionary Motive Is Something That Similar To The Emergency Savings Motive. The Scholars Such As Hariko And Watanabe (1997), Yao Et Al. (2011), Canova, Rattazzi And Webley (2005) And So On, Identified The Saving For Uncertainties As The Precautionary Savings Motive And Xiao And Noring (1994), Fisher And Anong (2012), Lee And Hanna (2013) And So On Identified It As The Emergency Savings Motive.

The Most Of The Theoretical And Empirical Researches All Over The World Confirmed That The Precautionary Savings Motive As A Magnitude Savings Motive. In 1975, Katona Has Identified The Most Significant Savings Motive Is The Emergency, Followed By The Desire To Save Money As The Reserve Of Necessities, With Saving For Interest And Bequest Motive Are Unimportant. Horioka And Watanabe (1997) Have Recognized Saving For The Retirement And Precautionary Motives Were Dominant Important Savings Motives After The Investigation Of Twelve Motives To Overall Household Saving In Japan. Xiao And Noring (1994) Also Have Verified The Most Frequently Mentioned Savings Motives Were Saving For Emergency, Purchase, And Retirement. Fisher And Montalto (2010) Figured Out That The Emergency And Retirement Savings Motives Were The Savings Motives That Significant While The Bequest Motive Was Not A Significant Savings Motive. Yao Et Al. (2011) Also Confirmed That Chinese Households Were More Likely To Save Money On Precautionary And Education Savings Motives Than American Households. Fisher And Anong (2012) Have Also Expressed That Precautionary And Retirement Motives Are The Most Magnitude Savings 
Motives. Birkeland (2013) Identified The Precautionary Motive As The Most Important Savings Motive And The Bequest Motive, The Calculation Motive And The Enterprise Motives Are Savings Motives That Are Less Important In The Netherlands. Yao And Xiao (2014), Le Blanc Et Al., (2015) Also Verify That Precautionary Motive Is A Significant Savings Motive.

So It Is Confirmed The Major Finding Of This Study Is Proved By The Different Researches All Over The World.

The Study Was Analyzed Four Demographic Variables; Gender, Marital Status, Age, Employment And Four SocioEconomic Variables; Main Income Source, Monthly Income, Dependent Children In A Family, Health Status Of The Respondent With Three Savings Motives Precautionary Savings Motive, Bequest Savings Motive And Lifecycle Savings Motive

\section{a) Bequest Savings Motive}

The Analysis Has Found That There Is An Association Between The Bequest Motive And Gender Which Indicates Gender Is Variable That Affect To The Decision Of Saving Money For Their Bequest.

And Also There Is An Association Between The Bequest Motive And The Dependent Children. It Is Proven That Whether Family Is Consisted With Dependent Children Or Not Is Changed The Decision To Save Money For The Bequest

\section{b) Precautionary Savings Motive}

The Tests Implied That Neither Of The Demographic Variable Nor Socio-Economic Variable Is Associated With The Precautionary Savings Motive.

\section{c) Life Cycle Savings Motive}

It Is Expressed That Three Variables Are Associated With The Life Cycle Motive. There Is An Association Between Life Cycle Motive And Marital Status Which Imply That Whether Been A Married Person Or Not Is Affect To The Decision Of Saving Money For Life Cycle Savings Motive. Also Employment And Main Income Level Of Individuals Are Other Two Variables That Have An Association With The Life Cycle Savings Motive.

\section{RECOMMENDATIONS}

The Results Of This Study Mainly Benefited To The Banking Industry In Sri Lanka. Introduce A Separate Fund Schemes To Save Money For Precautionary Situations

The Results Revealed That The Most Of The People Give Their First Priority To Save Money For Their Future Uncertainties. So Banks Can Be Introduced A Separate Fund Scheme To Save Money For The Emergency Situations. The Countries Like Usa Have Introduced Separate Fund Schemes To Save Money For The Retirement, Emergency Situations And So On. So There Is An Opportunity To Banks In Sri Lanka Also To Introduce A Separate Fund Scheme For Saving Money In Emergency Situations.

Promote Savings Accounts Rather Than Fixed Deposits

Especially They Can Promote The Savings Accounts Rather Than The Fixed Accounts Since People More Concern On Less Maturity Deposits Schemes In Order To Withdraw Their Reserves In Immediate Situations. The Fixed Accounts Also Short Term Matured Should Promote Among The People Rather Than Long Term Matured Fixed Deposits

\section{FURTHER STUDIES}

The Main Purpose Of This Study Is To Identify The Main Savings Motive Among Households In Kalutara District. This Is One Of The Initial Steps Of Searching Savings Motives In Sri Lanka So There Will Be More Opportunities To Start Searching In This Area.

Further Studies Can Examine The Savings Motives Of Upper Middle Class People To Determine Whether The Main Savings Motive For Their Savings Is For The Bequest. Sri Lanka Is A Cultural Country; So The Most Of The Parents Willing To Save Money For Their Children Rather Than Anything Else.

This Study Is Limited To The Particular Geographical Area Of Sri Lanka; So There Is An Opportunity To Future Researchers To Expend Their Researches To All Over The Country In Order To Determine The Most Common Reason To Save Money Of Sri Lankans Or Can Be Examine The Savings Motives Of Another Geographical Area In The Country

The Research Only Inspects Three Per-Determined Savings Motives And There Is A Space To Search What Are The Reasons To Save Money Of Sri Lankans' Rather Than Pre Determining Savings Motives Or Can Be Add Other Savings Motives In Order To Explore The Commonly Accepted Savings Motive. 


\section{REFERENCES}

1. Beta.Tutor2u.Net,(2015). Household Saving | Tutor2u. [Online] Available At: Http://Beta.Tutor2u.Net/Economics/Reference/Household-Saving [Accessed 27 Jul. 2015].

2. Birkeland, F. (2013). The Saving Motives Of Dutch Households And The Effect Of Individual Characteristics On The Importance Of Saving Motives.

3. Chudzian, J., Anioła-Mikołajczak, P. And Pataraia, L. (2015). Motives And Attitudes For Saving Among Young Georgians. Economics \& Sociology, 8(1), Pp.165-175.

4. Fisher, P. And Montalto, C. (2010). Effect Of Saving Motives And Horizon On Saving Behaviors. Journal Of Economic Psychology, 31(1), Pp.92-105.

5. Horioka, C. And Watanabe, W. (1997). Why Do People Save? A Micro-Analysis Of Motives For Household Saving In Japan. Economic Journal, 107(442), P.124.

6. Le Blanc, J., Porpiglia, A., Teppa, F., Zhu, J. And Ziegelmeyer, M. (2015.). Household Saving Behaviour And Credit Constraints In The Euro Area. Ssrn Electronic Journal.

7. Lee, J. (2012). Hierarchical Structure Of Saving Goals Among U.S. Households Using 1998 To 2007 Scf. Consumer Interests Annual.

8. Xiao, J. And Noring, F. (1994). Perceived Saving Motives And Hierarchical Financial Needs.

9. Yao, R., Wang, F., Weagley, R. And Liao, L. (2011). Household Saving Motives: Comparing American And Chinese Consumers. Family And Consumer Sciences Research Journal, 40(1), Pp.28-44.

10. Yao, R., Xiao, J. And Liao, L. (2014). Effects Of Age On Saving Motives Of Chinese Urban Consumers. J Fam Econ Iss, 36(2), Pp.224-238 